\title{
Loan Portfolio and Effect of Delinquency :( Case of Wisdom Micro Finance Institution, Soddo Branch)
}

\author{
Abera Abebe \\ Department of Agricultural Economics, Wolaita Sodo University
}

\begin{abstract}
The purpose the study was analyzing the effect of loan portfolio quality and effect of delinquency in Sodo Vision Fund Micro financing Institution. The study conducted in the clients received loan from the institution and office staff of Sodo vision fund micro finance institution. The selection of these target population were made at random sample by using an availability of sampling techniques were taken as a study of population. The data gathering tool employed in this was questionnaires and interviews among 56 member of clients and 6 staff member of the institution, Hence a set of questionnaires distributed to $68(100 \%)$ of male and $32(100 \%)$ of female and total sampling population were filled and returned. Thus, final result of analyze of the study was made based on questioners and interview from the given group of respondents and documents of the institution. The data was analyzed by using percentage and ranking methods. Generally the study contains problems and its approach review of related literatures. Finally, questionnaires were administrated the sample population the researcher prepared interview questions to both the clients and staff member and percent them to the respondents of sample population. The major intension of the researcher to improve loan portfolio quality and effect of delinquency among clients, and also to improve the culture of saving and repayment of the loan, creating awareness to the people/clients in over all areas of the loan.
\end{abstract}

Keywords: Loan, Effect, Delinquency Vision Fund

DOI: $10.7176 /$ JPID/49-03

Publication date: April $30^{\text {th }} 2019$

\section{INTRODUCTION}

\subsection{Background of the study}

The Vision Fund Microfinance Institution is a MFI which operating in all Zones in the SNNPR. VFMI of Soddo branch is one of a branch found in southern nation, nationalities and people regional state in Soddo town. Soddo Town is demarcated and surrounded by Soddo Zuriya Woreda in four directions. It is sighted on the distance of $165 \mathrm{~km}$ from Hawassa, which is the capital city of southern region. (Operating Manual, 2000).The institution focuses on the delivery of basic and creation of enabling environment for the cultivation, development and expansion of micro enterprise that create productive employment and income generation for the urban and rural poor. (Worku, 2000)

Delinquency under mines productivity of the credit officers and of the portfolio in general loan losses begins to erode the capital base of the MFI. As a result, everybody in the MFI must understand why quality is the organizations top priority. Though, the effect of delinquency results declining portfolio quality was one of the major problems in the performance of the institution and this is lead to defeat profit that will be analysed in the research analysis.

\subsection{Statement of the problem}

One of the key issues facing the microfinance industry today is the high percentage of loans that are not paid on the due date. Delinquency is the largely serious problem which plays a critical role on profitability of MFI. If the loan portfolio is not paid on the due date MFI cannot achieve its goal. Delinquency is the main problem that decreases the institutions loan portfolio. Delinquency caused by different types of problems, but this research paper will attempts to address the following major problem areas (Worku 2000).

This research work was identified; the paper would attempt to address the following major areas: Are the policies, rule and regulations and manuals in placed to guide and govern the credit management and credit officers to perform accordingly through adequate knowledge of the micro financing activities in a manner of good portfolio quality and officers during screening and what methodology being used to guarantee the repayment of loan?

\subsection{Objective of the study}

1.3.1 General Objective

The general objective of the study was to assess the loan portfolio quality and identify the effect of delinquency in Sodo Vision Fund Micro Finance Institution.

1.3.2 Specific Objective

1. To identify the growth and capital of the institution by keeping loan portfolio quality. 
2. To identify the degree of follow-up and supervision after providing loan to the clients.

\section{Methodolgy}

\subsection{Description of the Study area}

2.1.1 Location Wolaita sodo town was the administrative center of wolaita Zone and it had a latitude and longitude of $654^{\prime} \mathrm{N} 3745^{\prime} \mathrm{E} / 6,900 \mathrm{~N} 37.750^{\prime} \mathrm{E}$ with an elevation of $1600 \mathrm{~m}$ above sea level .This town was located $333 \mathrm{kms}$ from Addis Ababa and $170 \mathrm{~km}$ away from the SNNP's region capital Hawassa. Based on the 2007 census conducted by the central statistical Authority (CSA), this town had a total population of 76,050, of whom 40,140 were men and 35,910 were women. Accordingly, the majorities of inhabitants were Protestants and were about $54.61 \%$, Ethiopian Orthodox Christianity $38.43 \%$, Muslim $4.76 \%$ and catholic were about $1.28 \%$.

\subsection{Source and types of data}

Both primary and secondary sources of data were applied to gather the appropriate information. For this study, the sources of the primary data were structured questionnaires, structured interviews if necessary, schedule and that of the secondary data were documents such as annual \& semi- annual reports published and unpublished documents and others that were appropriate for both types of data (qualitative and quantitative data) had been gathered through semi-structured questionnaires using schedule interview and others.

\subsection{Sampling Techniques}

In this research paper, it would be tried to use relevant information to gather necessary data regarding the study of loan portfolio quality and effect of delinquency of Vision Fund Micro Finance of Soddo Branch. The selection of sample would be done by using judgment sampling technique from all finance department, operating department and number of clients. The population size of clients in Sodo Branch would be determined to minimize the large number of clients, staffs number, and high amount of delinquency. For this study ; data gathering tool employed in this was questionnaires and interviews among 56 member of clients and 6 staff member of the institution

\subsection{Method of Data Analysis}

The study's method of data analysis would descriptive and inferential. The researcher may use the responses from the closed ended questionnaire compared for the frequency distribution and would be tabulated in terms of percentage. The responses from interview, open ended questionnaires, observations and document analysis would be summarized and finally generalizations would be made based on the result of the study.

\section{Data Analysis and Presentation}

This study attempted to assess loan outstanding and consequence of delinquency and loan collection trend during in one of MFI, Vision Fund Soddo branch the last three years by sectors. Descriptive data on basic information enabling analysis of the VFMFI performance in regards to loan performance and cause of delinquency was collected. The information pertain to the three year financial data covering aspects of loan disbursement application at the branch for different customers and supporting human capital data at the branch which will have the potential to affect the micro finance institutions performance. The general approach followed in the data analysis is essentially a cross sectional examination of the vigorous of the loan performance in the VFMFI in the past three years.

In examining the performance of the VFMFI regarding loan performance, the percentage discrepancy of the sectoral loan applications were analysed. A comparison of the loan outstanding and the loan portfolio quality was made on percentage basis. A cross comparison between the sectors was also made and in tandem with it the evaluation of the loan disbursement direction in the branch MFI was examined. To do that the percentage of the loan outstanding in each year was calculated and the magnitude of this percentage was compared (i.e. in the table). Likewise a comparison of the percentage distribution of loan disbursement and collection was made for the period of the study. While understanding the need to use more comprehensive approach in loan performance investigation the researcher resorted to use different table and its description for the evaluation due to the paucity of data in the branch. Accordingly, in evaluating the loan performance the qualitative character of the loan percentage of the outstanding loan in years under consideration superiority was calculated and examined both for magnitude and trends. Finally, in the evaluation of the qualitative interview and questionnaires the responses of the selected clients was transcribed and coded and complaints were lumped under a common subject. The frequency distribution of the respondents falling in each category was determined as a percentage from the total interviewees. This information is considered to be crucial as it gives a picture of the customers view towards the VFMFIs. Likewise, documents in the Vision Fund micro finance institution were assessed critically to examine the major challenges in regards to loan applications. 


\section{Loan Outstanding and Portfolio Quality Trends of Soddo VFMFI from 2013 to 2015}

The respective years of loan outstanding balance was indicated here below in the table. 1. Compared to the target for the year, the institution has been able to achieve only $89 \%, 95 \%$ and $98 \%$ of its loan outstanding target for the respective periods. The difference is not attributed due to shortage of fund and lessens of required number of loans/clients.

Table.1 Targeted Vs Actual Loan outstanding Relationship

\begin{tabular}{|l|l|l|l|}
\hline \multirow{2}{*}{ Item } & \multicolumn{3}{|c|}{ Year } \\
\cline { 2 - 4 } & 2013 & 2014 & 2015 \\
\hline Targeted Loan Outstanding & $5,802,733$ & $5,892,143$ & $5,903,646$ \\
\hline Actual Loan outstanding & $5,164,432$ & $5,597,536$ & $5,785,573$ \\
\hline Percentage & $89 \%$ & $95 \%$ & $98 \%$ \\
\hline
\end{tabular}

Source: Drawn from the secondary data (of VFMFI by the researcher)

According to the secondary data of VFMFI Soddo Branch, loan outstanding and portfolio quality relation is demonstrated to verify the fact. Table. 2 shows the gross loan portfolio/loan outstanding and portfolio at risk $>30$ days of the institution from year 2013 to 2015 .

Table.2 Loan outstanding and portfolio quality relationship

\begin{tabular}{|l|l|l|l|}
\hline & $\begin{array}{l}2013 \\
\text { In birr }\end{array}$ & $\begin{array}{l}2014 \\
\text { In birr }\end{array}$ & $\begin{array}{l}2015 \\
\text { In birr }\end{array}$ \\
\hline Gortfolio Quality & $5,164,432$ & $5,597,536$ & $5,597,536$ \\
\hline Loan outstanding increased by & - & $8.39 \%$ & $3.36 \%$ \\
\hline Portfolio at Risk > 30 Days & $4.1 \%$ & $4.8 \%$ & $7.5 \%$ \\
\hline Portfolio at Risk > 30 Days increased by & - & $37.7 \%$ & $191.12 \%$ \\
\hline Write offs / Portfolio & $1.98 \%$ & $2.06 \%$ & $3.87 \%$ \\
\hline Write offs / Portfolio increased by & - & $43.16 \%$ & $305.59 \%$ \\
\hline Portfolio at Risk Plus Write offs & $4.08 \%$ & $4.86 \%$ & $10.37 \%$ \\
\hline
\end{tabular}

Source: Drawn from the secondary data (of VFMFI by the researcher)

According to the secondary data analysis in the table above, there is increasing trend in the loan outstanding from year to year, while there is decreasing trend of loan portfolio quality from year to year. Discussions with focus group and the key informant from the institution have described the declining loan portfolio quality trend in the following manner. The major reason for the declining loan portfolio quality trend for three consecutive years was the client didn't bring its repayment on time frame/due date; this is because of inflation, lack of rainfall and drought are the major reason for the first two years and in addition, the clients were discouraged to effect their repayment considering political reason in year 2015. This is because the concerned legal bodies are actively engaged in the process of national election and they don't want to irritate people by taking court case to enforce the client (personal contact during interview).

Portfolio Mix:

Table: 3, Portfolio Allotment in Sectoral Activities.

\begin{tabular}{|l|c|c|c|}
\hline \multirow{2}{*}{ Item } & \multicolumn{2}{c|}{ Year } \\
\cline { 2 - 4 } & 2013 & 2014 & 2015 \\
\hline Gross Loan Portfolio & $5,164,432$ & $5,597,536$ & $5,597,536$ \\
\hline Loan balance in commerce/ trade & $55 \%$ & $56 \%$ & $56 \%$ \\
\hline Loan balance in agriculture & $33 \%$ & $34 \%$ & $33 \%$ \\
\hline Individual loan & $12 \%$ & $10 \%$ & $11 \%$ \\
\hline Total & $\mathbf{1 0 0 \%}$ & $\mathbf{1 0 0 \%}$ & $\mathbf{1 0 0 \%}$ \\
\hline
\end{tabular}

(Source: secondary data analysis from Soddo VFMFI)

Portfolio mix analysis by sectoral activities indicates that $60 \%, 61 \%$, and $63 \%$ of the loan portfolio of each year was invested in micro enterprises that are in commerce/trade, service and agricultural production businesses. The accomplishment in terms of portfolio diversification was found encouraging and consistent with the institution's strategy of maintaining diversified loan portfolio in different sectors with a significant shift from agricultural balloon loans. A detailed percentage of loan portfolio distributions in sectoral activities are as follows:

\section{Active Clients:}

The following table shows that the comparison of total number of active clients Vs the total targeted client's for each year. Distribution of the active clients in lending mythology indicates that $38 \%$ are in community banking, $40 \%$ in solidarity groups and $22 \%$ in individual lending mythologies. The rise in individual lending mythology is attributed to the consumer and micro enterprise loans provided on individual basis (source: Secondary data analysis). 
Table.4 Targeted Client Vs Actual Client and gender relationship

\begin{tabular}{|l|c|c|c|}
\hline \multirow{2}{*}{ Description } & \multicolumn{3}{|c|}{ Year } \\
\cline { 2 - 4 } & 2013 & 2014 & 2015 \\
\hline Targeted Client & 3781 & 3613 & 3732 \\
\hline Actual Client & 3403 & 3360 & 3545 \\
\hline Percentage & $90 \%$, & $93 \%$ & $95 \%$ \\
\hline
\end{tabular}

(Source: secondary data analysis from Soddo VFMFI)

The number of active women clients for three consecutive years was 2212 (65\%), 2285 (68\%), and 2482 $(70 \%)$ out of total active clientele. The institution is still keeping growing its active women clients though it is still below the target of $70 \%, 75 \%$, and $80 \%$ of each year. There are improvements in targeting women clients in loan disbursement and this has contributed to the increase in the percentage. It was also evidenced from the percentage of female borrowers increased $3 \%$ and $2 \%$ respectively. (Source: Computed by VFMFI and drawn from secondary data by the researcher)

\section{Demographic Characteristics of sample HHs}

From the questionnaires distributed following demographic characteristics of selected HHs recorded. Table.5

Age, gender, and marital status of the selected HHs

\begin{tabular}{|l|l|l|l|l|l|}
\hline Items & Male & Female & Total & Married & Single \\
\hline $0-18$ years & - & - & - & - & - \\
\hline $18-40$ Years & 22 & 9 & 31 & 25 & 6 \\
\hline $40-60$ years & 5 & 4 & 9 & 8 & 1 \\
\hline$>60$ years & 10 & 6 & 16 & 16 & - \\
\hline Total & $\mathbf{3 7}$ & $\mathbf{1 9}$ & $\mathbf{5 6}$ & $\mathbf{4 9}$ & $\mathbf{7}$ \\
\hline
\end{tabular}

(Source: Survey result, 2015)

The data shows that $87.5 \%$ of the selected HHs of the clients is married and $33.93 \%$ is female. Thus, from the above table we can see that male and married clients are found as most delinquent as that of male \& unmarried clients of the institution.

Table. 6 what is your level of education?

\begin{tabular}{|c|c|c|c|c|}
\hline Items & Male & Female & Total & $\%$ \\
\hline No educational background & 1 & 1 & 2 & 3.57 \\
\hline 1-6grade & 6 & 19 & 25 & 44.64 \\
\hline $7-8$ grade & 12 & 12 & 24 & 42.86 \\
\hline $9-12$ grade & 3 & 2 & 5 & 8.93 \\
\hline$>12$ grade & - & - & - & - \\
\hline Total & 22 & 34 & 56 & 100 \\
\hline
\end{tabular}

From the table above, people with educational background 1-6 grade level were found to be most delinquent covering $44.64 \%$ of the respondent. People with educational back ground 12 and above grade level were found to be the least delinquent with $0 \%$ response.

Table 7. What kind of loans do the delinquent clients take?

\begin{tabular}{|l|l|l|}
\hline Item & Number/frequency & Percent \\
\hline Commercial/Trade Loan & 38 & $68 \%$ \\
\hline Agricultural Loan & 13 & $23 \%$ \\
\hline Individual loan & 5 & $9 \%$ \\
\hline Total & $\mathbf{5 6}$ & $\mathbf{1 0 0 \%}$ \\
\hline
\end{tabular}

Source: survey result/Primary data

From the total respondent, $68 \%$ of the clients said that the clients who received loan for commerce get delinquent than agri loan and individual loan.

Factors Affecting Loan Repayment

Problems related with loan portfolio quality have been reported for Vision Fund MFI. Loan portfolio quality is the largest and most important asset of VFFIs. Therefore, VFMFI should put maximum effort to ensure higher quality of this asset, yet certain portion of this asset will remain uncollected. These uncollected assets are called delinquent asset on delinquent loan that have been written off by the MFI.

The major factors that cause delinquency are categorized in to three parts.

1. Institutional/ organizational factor

2. Client factor

3. External factor (Secondary Data Analysis) Table: 8, what factors affecting your portfolio quality/Loan repayment trend on due date? 


\begin{tabular}{|c|c|c|c|c|c|c|}
\hline \multirow[t]{2}{*}{ What Factors } & \multicolumn{3}{|c|}{$\begin{array}{l}\text { Client } \\
\text { respondent }\end{array}$} & \multicolumn{3}{|c|}{$\begin{array}{l}\text { Employee } \\
\text { respondent }\end{array}$} \\
\hline & Yes & No & Total & Yes & No & Total \\
\hline $\begin{array}{l}\text { Lack of Staff capacity to understand credit discipline } \\
\text { (Institutional F.) }\end{array}$ & $8 \%$ & $7 \%$ & $15 \%$ & $50 \%$ & $50 \%$ & $100 \%$ \\
\hline $\begin{array}{l}\text { No training of business to clients prior to providing } \\
\text { each loan (Institutional F.) }\end{array}$ & $46 \%$ & $32 \%$ & $100 \%$ & $67 \%$ & $33 \%$ & $100 \%$ \\
\hline $\begin{array}{l}\text { With no observation of client's business prior loan } \\
\text { provision (Institutional F.) }\end{array}$ & $73 \%$ & $27 \%$ & $100 \%$ & $67 \%$ & $33 \%$ & $100 \%$ \\
\hline $\begin{array}{l}\text { Some loans provided on the basis of favouritism } \\
\text { (relatives/friendship) }\end{array}$ & $70 \%$ & $30 \%$ & $100 \%$ & $50 \%$ & $50 \%$ & $100 \%$ \\
\hline $\begin{array}{l}\text { Loan size is too big when comparing paying capacity } \\
\text { of the client (Institutional F.) }\end{array}$ & $14 \%$ & $86 \%$ & $100 \%$ & $17 \%$ & $83 \%$ & $100 \%$ \\
\hline $\begin{array}{l}\text { Poor follow-up and monitoring after immediate } \\
\text { disbursement (Institutional F.) }\end{array}$ & $88 \%$ & $12 \%$ & $100 \%$ & $67 \%$ & $33 \%$ & $100 \%$ \\
\hline $\begin{array}{l}\text { Inadequate training of staff of portfolio and } \\
\text { delinquency management (Institutional F.) }\end{array}$ & $5 \%$ & - & $5 \%$ & $67 \%$ & $33 \%$ & $100 \%$ \\
\hline Weak selection/screening of group member (Client f.) & $66 \%$ & $34 \%$ & $100 \%$ & $67 \%$ & $33 \%$ & $100 \%$ \\
\hline Weak selection of committee leaders (Client f.) & $71 \%$ & $29 \%$ & $100 \%$ & $67 \%$ & $33 \%$ & $100 \%$ \\
\hline Unwillingness to pay (Client f.) & $55 \%$ & $45 \%$ & $100 \%$ & $83 \%$ & $17 \%$ & $100 \%$ \\
\hline Willingness but unable to pay (Client f.) & $52 \%$ & $48 \%$ & $100 \%$ & $50 \%$ & $50 \%$ & $100 \%$ \\
\hline Client death (Client f.) & $46 \%$ & $54 \%$ & $100 \%$ & $83 \%$ & $17 \%$ & $100 \%$ \\
\hline Lack of rain fall/non production (External F.) & $88 \%$ & $12 \%$ & $100 \%$ & $67 \%$ & $33 \%$ & $100 \%$ \\
\hline $\begin{array}{l}\text { Inflation /Business failure/Market computation problem } \\
\text { (External f.) }\end{array}$ & $84 \%$ & $16 \%$ & $100 \%$ & $83 \%$ & $17 \%$ & $100 \%$ \\
\hline Political abuse (External f.) & $89 \%$ & $11 \%$ & $100 \%$ & $83 \%$ & $17 \%$ & $100 \%$ \\
\hline
\end{tabular}

(Source: Survey result, 2015).

According to the primary data analysis in the table 8 above, the majority of respondent of selected HHs and employees said that Portfolio quality problem is caused by three major factors, among that, external factors are accounted as the $1^{\text {st }}$, client factor is the $2^{\text {nd }}$ and institutional factor is the $3^{\text {rd }}$ one. The As a factor an institutional/organizational factor mostly refers to the institution's human resource capacity. The gaps more or less linked with knowledge and skill which unless otherwise lead Vision Fund micro finance institution to provide quality service and stay competent in the business.

The client factor predominantly refers to the client's trustworthiness to the business form screening to repayment of the loan, while external factor principally refers to the factors that affect the business of the client beyond their capacity/uncontrollable.

Table 7 shows that the loan portfolio quality of VFMFI is affected by both controllable and uncontrollable factors. Though, Controllable factors of loan delinquency can be managed by the institution but still such kinds of factors existing in the lending and borrowing process. If the VFMFI prolong lending loan in the same manner the repayment of loan must be delayed and the delinquency will arise.

\section{Clients training}

Have you taken training prior to each loan?

Clients were asked to verify whether they have taken training prior to each loan.

Table: 9, prior to coming VF microfinance, have you taken any training to your business?

\begin{tabular}{|l|l|l|}
\hline Respondents & Number & $\%$ \\
\hline Yes & 20 & 35.7 \\
\hline No & 36 & 64.3 \\
\hline Total & $\mathbf{5 6}$ & $\mathbf{1 0 0}$ \\
\hline
\end{tabular}

(Source: Survey result, 2015)

Most of respondents $36(64.3 \%)$ said that training was not given prior to each loan, the rest $20(35.7 \%)$ of them taking training.

This shows that many clients were not provided business training/awareness creation prior to each loan, meaning the clients receiving loan without any awareness about the business. This type of trend leads them to spend money in unexpected plan. If so, at the time of repayment they may not get ready to pay the repayment. If the repayment is not done on the due date and delinquency will be occurred.

\section{Loan officers job satisfaction and their diligence}

Loan officers job satisfaction and their diligence is most important to the institution, because more satisfied employees in a given institution can accomplish his/her assignment or duties on time. Especially loan officers 
should be motivated or encouraged by different types of incentives.

If the institution needs to keep loan portfolio quality, it has to give focus on the needs of employees, including employee satisfaction, motivation, and operational efficiency. If employees are happy with the institution which they work, they will produce a higher level of services and keep loan portfolio quality as the institution needs, this section put emphasis on examining job satisfaction of employees and their diligence to follow-up clients and to collect the repayment on the due date after loan disbursement was made.

Respondents were asked the loan officer's diligence to follow-up clients and collecting the repayment on time. The response is presented in the table below.

Table: 10, Aare you satisfied in your job position?

\begin{tabular}{|l|l|l|}
\hline \multicolumn{1}{|c|}{ Respondents } & Number & \% \\
\hline Very strong & 10 & 17.8 \\
\hline Medium & 15 & 26.8 \\
\hline Weak & 25 & 44.6 \\
\hline Very weak & 6 & 10.8 \\
\hline Total & $\mathbf{5 6}$ & $\mathbf{1 0 0}$ \\
\hline
\end{tabular}

(Source: survey result, 2015)

As indicated in the table $10,44.6 \%$ of the respondents said that the loan officers are weak to follow-up clients and also to collect the repayment on the due date. This shows that the loan officers are dissatisfied by their job in connection with the institution policy. To assure this fact, the researcher interviewed six of the loan officers and the loan officer said that it is true because staff remuneration is not enough when comparing with the work load and also no encouraging incentive scheme policy, as the result no satisfaction of job.

\section{Client Screening/Selection criterion}

As mentioned in the methodology of the lending, the institution delivers loan service to the clients those who are screened by themselves and forms a group. Some of the respondents were asked the strong-ness of client's screening/selection between themselves (group member selection). The following table presents the response of the respondents.

Table.11 what are the criteria's used to select costumers between themselves?

\begin{tabular}{|l|l|l|}
\hline Respondents & Number & $\%$ \\
\hline Definite/strict & 4 & 66.7 \\
\hline Non-interventionist/tolerant & 2 & 33.3 \\
\hline Total & $\mathbf{6}$ & $\mathbf{1 0 0}$ \\
\hline
\end{tabular}

(Source: survey result, 2015)

As indicated in the table $11,33.3 \%$ of respondents said that some clients were not screened or selected strongly/vigilantly but not all; this is because of carelessness or neighbourly relationship. This shows that client selection or screening is not strong and as the result loan repayment was delayed.

Loan given by favouritism (relatives/friendship)

Clients were asked whether they encountered the loan which is given by favouritism or not. The following table presents their response.

Table. 12 have you encountered any loan which is given by favouritism (relatives and friendship)?

\begin{tabular}{|l|c|c|}
\hline \multicolumn{1}{|c|}{ Respondents } & Number & $\%$ \\
\hline Encountered & \multicolumn{1}{|c|}{30} & 53.6 \\
\hline Not encountered & 26 & 46.4 \\
\hline Total & $\mathbf{5 6}$ & $\mathbf{1 0 0}$ \\
\hline
\end{tabular}

(Source: survey result, 2015)

As indicated in the table $12,53.6 \%$ of the clients said that there is a loan which is given by favouritism. This shows that there is lack of care of managing loan policy and the loan officer is not giving attention to the institution's asset.

If loans are given on the basis of favouritism, the client may attempt to delay payment or default. They often hope that their friend in the VFMFI staff will encourage the organization to write off the loan rather than take the client to court and seize their property. This can be problem with small business loans. Often the larger the loan size, the greater the incentive for friends of credit officers to receive these loans. 
Table 13. How much loan do you provide for your client and is there any change of interest rate from year to year?

\begin{tabular}{|l|l|l|l|l|}
\hline Type of loan & $\begin{array}{l}\text { Previous } \\
\text { Loan(Birr) }\end{array}$ & $\begin{array}{l}\text { Previous } \\
\text { Interest rate }\end{array}$ & $\begin{array}{l}\text { New } \\
\text { Loan(Birr) }\end{array}$ & $\begin{array}{l}\text { New } \\
\text { Interest rate }\end{array}$ \\
\hline Commerce/enterprise Loan & 3000 & $12.50 \%$ & 4000 & $15 \%$ \\
\hline Individual loan for consumption & 1500 & $15 \%$ & 3000 & $19 \%$ \\
\hline Individual loan for business & 25000 & $12.50 \%$ & 50000 Ceiling & $15 \%$ \\
\hline Agri loan & 1500 & $15 \%$ & 2000 & $19.50 \%$ \\
\hline Agri business & 1500 & $15 \%$ & 2500 & $17 \%$ \\
\hline
\end{tabular}

(Source: Survey result/primary data)

According to the data shows in the table above, the loan given to the client and its interest rate change was too large without considering their business vision. This shows that extra funds may go towards personal use. When the loan needs to be repaid, the client cannot pay back without de-capitalizing the business. In other words, the client has to use the net equity of the business to pay back the loan, or the client post ponds the repayment. Postponement of the repayment leads to delinquency.

A significant change/raise of interest rate of loan can discourage clients and imposing burden in the course of business activity and repayment, because of this unexpected delinquency will occur and the fund disbursement said to be at risk. But the manager justified regarding to the increment of interest rate and loan size is for the sake of the benefit of the institution and client, but the reason is to discourage the some clients who are not peasant but demanding to take agri and consumption loans by increasing the interest rate. This is, in my point of view can mislead both the institution and the clients because if the clients selected to the loan through favouritism and the credit officer not competence to the work of credit discipline to keep the rule and regulation of the institution.

\section{CONCLUTION AND RECOMMENDTION}

\subsection{Conclusion}

Vision Fund micro finance institution has exceptional insurance policy. VFMFI insurance policy helps the clients and the institution itself. The clients those who are taking loan service will contribute two per cent of the loan for insurance fee and contributed insurance fee is deposited in the account of the institution and it helps to cover the loan amount at the time of clients death.

Portfolio quality problem is caused by different factors. These factors that cause delinquency are, no staff capacity to understand credit discipline, no training of business prior to providing each loan to the clients, poor client screening, loan are provided with no observation of clients business, poor follow up and monitoring after immediate loan disbursement, in adequate training of staff, and large size of loan provision and imposing significant interest rate on the loan to the client.

Prevention is always is always better than cure, so a clear understanding by the client that delinquency will not be tolerated is key to keeping the institution from getting out of hand. VFMFIs need to have clear and effective credit policy and procedures approved by the board of directors (BOD) that are followed by credit officer.

\subsection{Recommendation}

Manager and credit officers are need to pay due attentions to details. Credit officers must respond swiftly to details and also respond quickly to problem clients in their portfolios. The manager (credit supervisor) must respond quickly to solve to credit officers problem.

It is very important that practitioners watch carefully that policies are followed once they are put in place. If things are not working, then the institution needs to identify the problem areas and fix them quickly.

If MFI can reduce delinquency and get the basics of finance right, then the organizations over all goals can likely make a significant contribution to the economic development of the poor in a country. While reducing delinquency is not the only determinant in successful sustainability of MFIs, it is an important building block.

Finally I would like to recommend the following things to Vision Fund MFI to reduce delinquency and to improve the institutions portfolio quality and sustainability of financial and operational activities.

1. Providing training to credit officers is most important to maintain understanding of credit discipline.

2. Before accepting new clients, observation of clients business is very essential and should be a responsibility of a credit officer and it helps to determine the loan size.

3. Credit officers should visit the client and provide training prior to each loan.

4. Strict screening/selection of group members between themselves is very important.

5. Groups should select each other based on trust and knowledge of each other's business and character. They should operate their business and preferably live in the same area. Because it helps to maintain relationship between themselves and easy to collect the repayment on the due date from each client. 
6. The formation of a strong group member and committee leaders is key to prevent high delinquency. Because committee leaders are responsible to collect and submit the payments to the lender.

7. Loan size and terms should be based on the clients capacity to pay dept. capacity is measured by observing clients business and income generation.

8. Strong follow-up and monitoring after the disbursement is very essential to prevent delinquency problem. Because prevention is better than cure.

9. Maintaining (setting) insurance policy has great contribution to compensate damaged loan. Eg. Death of group member.

\section{Referance}

Craig F. Churchill, Managing growth: the organizational Architecture of Microfinance Institutions. ACCION International, 1999.

http://financialdictionary.thefreedictionary.com/loan+portfolio(20-Dec-09)

Katherine Strains (1995), the hidden beast delinquency in micro enterprise Organizational Operation Manual \& related Documents, (VFMFIs, 1998)

Robert Peck Christen: Banking serves for the poor (2003).

Steam, Katherine (1999), method for managing delinquency.

Teshome Yohannes Dayesso, (2000). Growth with a poor quality is a death sentence for MFI. Buusaa Gonofaa MFI.

Teshome Yohannes Dayesso, (2000). Analyzing the institutional development of MFIs, Buusaa Gonofaa MFI. 